\title{
Association between phytoplankton and Vibrio spp. along the southwest coast of India: a mesocosm experiment
}

\author{
Ann-Sofi Rehnstam-Holm ${ }^{1, *}$, Anna Godhe ${ }^{2}$, Karolina Härnström ${ }^{2}$, Pendru Raghunath ${ }^{3}$, \\ V. Saravanan ${ }^{3}$, Betty Collin ${ }^{1}$, Indrani Karunasagar ${ }^{3}$, Iddya Karunasagar ${ }^{3}$ \\ ${ }^{1}$ Aquatic Biology and Chemistry (ABC), Kristianstad University, 29188 Kristianstad, Sweden \\ ${ }^{2}$ Department of Marine Ecology, University of Gothenburg, Box 461, 40530 Göteborg, Sweden \\ ${ }^{3}$ Department of Fishery Microbiology, Karnataka Veterinary, Animal and Fisheries Sciences University, College of Fisheries, \\ Mangalore 575 002, India
}

\begin{abstract}
We report the results from a mesocosm study investigating the interrelationship between microalgae and vibrios. The mesocosms were inoculated with plankton, plankton + sediment, or sediment. We followed the diatom bloom and increases in the abundance of Vibrio spp. and $V$. parahaemolyticus in conjunction with several environmental variables in all mesocosms and at a reference site. The dominating diatom genera were also identified. Temperature, salinity, and $\mathrm{pH}$ were nearly invariant in the mesocosms and did not contribute to the results. The principal environmental variables that correlated to vibrio abundance were total bacterial plate counts, phosphorus and ammonia (positive relationship), and oxygen and silica (negative). Nitrate, total bacterial counts and chlorophyll a (chl a) did not correlate with vibrio growth. The highest diatom abundances were followed by increases in vibrios in all mesocosms. This was also observed in field sampling. Together, these results suggest that diatom blooms could support Vibrio spp. growth. V. parahaemolyticus was initially favoured by sediment. The contribution of $V$. parahaemolyticus to the total bacterial population was low, on average $0.5 \%$, but constituted a rather high proportion of the vibrio population in the mesocosm systems, i.e. on average $18 \%$. Some of the identified diatom genera, e.g. Chaetoceros and Skeletonema, were negatively correlated to vibrios, while Coscinodiscus was positively correlated. The results indicate that phytoplankton blooms, when recorded as high levels of chl a, should be used with caution as predictors for future vibrio epidemics, since the origin of the chl a might have a significant effect on vibrio abundance.
\end{abstract}

KEY WORDS: Mesocosm · Phytoplankton blooms · Vibrio spp.

Resale or republication not permitted without written consent of the publisher

\section{INTRODUCTION}

The bacterial family Vibrionaceae encompasses a diverse group of heterotrophic bacteria. They are indigenous to estuarine and seawater environments, and have an important role in the decomposition of both particulate and dissolved organic matter (Fukami et al. 1985). A considerable number of pathogenic species have been described (Thompson et al. 2006), including important human pathogens, such as Vibrio cholerae, V. parahaemolyticus, and V. vulnificus. Vib- rios have a broad repertoire of lifestyles, including the human intestine, particulate-associated, free living, in nutrient-rich or -poor environments and in a wide range of salinities (Mueller et al. 2007).

Vibrio parahaemolyticus are common inhabitants of coastal waters, shellfish and fish in India, and an estimated level of $10 \%$ of all diarrhoeal diseases in Kolkata, India, has been related to V. parahaemolyticus infections (Deepanjali et al. 2005). About $2 \%$ of environmental $V$. parahaemolyticus isolates are pathogenic, but this number can differ substantially be- 
tween seasons and geographic areas (DePaola et al. 2003, Deepanjali et al. 2005). In oysters collected from locations along the southwest coast of India, all were positive for $V$. parahaemolyticus, and $33 \%$ of the samples contained potentially pathogenic strains (Parvathi et al. 2006).

For a long time, marine bacteria have been observed to be associated with phytoplankton, as free-living, directly attached to the algae, or living inside the algae (ZoBell 1941, Siebuth 1968). Thus, phytoplankton as a group can be considered as bacterial 'incubators'. We now know that a multitude of interactions between bacteria and algae can exist simultaneously, but differ in space and time (Acinas et al. 1997, Karl 2007). During phytoplankton blooms, particulate and dissolved organic matter (POM and DOM) undergo dramatic changes, and this variation is accompanied by strong shifts in bacterial abundance and species composition (Smith et al. 1995, Nayak et al. 2000). Bacterial growth rates have been shown to increase during the decline phase of the blooms, and this means that phytoplankton blooms have the potential to support explosive growth of marine bacteria, including vibrios (Rehnstam et al. 1993, Mouriño-Pérez et al. 2003, Pinhassi \& Berman 2003). Indeed, vibrios seem to be well adapted, physiologically, to exploit nutrient pulses in the environment; they can survive under long periods of substrate limitation, they maintain high ribosome content after they switch to starvation conditions, and they show strong chemotaxis towards ecologically relevant compounds (Holmquist \& Kjelleberg 1993, Yu et al. 1993, Eilers et al. 2000, Armada et al. 2003). A strong link has been observed between algal blooms and high numbers of Vibrio spp. that are pathogenic to humans (Lobitz et al. 2000). Such a relationship has been recorded, e.g. in Hong Kong (Kwan et al. 2003), where an increase of cholera cases could be predicted by an increase in ciguatera poisoning caused by consumption of fish that have fed on a toxic benthic dinoflagellate. It has also been shown that $V$. cholerae proliferate while attached to copepods (Huq et al. 1983, Mueller et al. 2007). Furthermore, V. cholerae as well as other Vibrio spp. can grow rapidly on DOM as well as POM (Mouriño-Pérez et al. 2003) and quickly switch between a free-living stage and a stage attached to particles (Worden et al. 2006). Evidently, the periodicity and spread of Vibriorelated diseases has a strong connection to the ecology of Vibrio spp., but the processes are still not understood (Munroe \& Colwell 1996).

Little knowledge exists regarding vibrio abundances during different kinds of phytoplankton blooms, and it is not known whether vibrios have a preference for any specific algal species, although dinoflagellates have been suggested as possible candidates (Eiler et al. 2006). Accordingly, it is important to develop models of bacteria-phytoplankton dynamics as tools for understanding marine settings and for reducing unwanted environmental effects on global health.

In previous studies, mesocosms have proved to be well suited for large-scale investigations in many different environments (e.g. Bussaard et al. 2005). They enable replication and allow control of the examined system, while preserving many of the natural conditions. Here, we report the results from a mesocosm study of the interrelationship between algae and vibrios performed in Mangalore, India, during the period 28 December 2005 to 13 January 2006. Mesocosms were inoculated with plankton, sediment, or plankton + sediment, and the development of a diatom bloom and a consecutive increase in Vibrio spp. and V. parahaemolyticus abundance was followed in conjunction with many other variables. Sediment was employed in the mesocosm experiments to play 2 distinct roles: (1) a prolonged diatom bloom can be achieved as a result of germination of diatom resting stages from sediments, and can generate different species compositions compared to plankton inocula (Härnström et al. 2007); (2) different Vibrio spp. can be associated with either algae or sediment (Urakawa et al. 2000). Thus, inclusion of sediment, along with a plankton inoculum, provides 2 potentially different algae and vibrio inocula. $V$. parahaemolyticus was chosen because this species is the most abundant human vibrio pathogen in the area. The mesocosm studies were compared to field samples that were obtained during the same time period and analysed in parallel.

\section{MATERIALS AND METHODS}

Mesocosms. The mesocosm experiment was undertaken at the College of Fisheries, Mangalore, India $\left(12^{\circ} 52^{\prime} \mathrm{N}, 74^{\circ} 53^{\prime} \mathrm{E}\right)$. The experiment ran from $28 \mathrm{De}-$ cember 2005 to 13 January 2006, inside a covered hall. Sediment cores were collected with a gravity corer 35 nautical miles $(56 \mathrm{~km})$ from Mangalore at a water depth of $30 \mathrm{~m}$, and the cores were immediately sampled on board ship. Overlying water was carefully drained, and the top $5 \mathrm{~mm}$ of sediment were subsampled into a plastic cup. At the same station, phytoplankton were sampled by several net tows $(10 \mu \mathrm{m}$ mesh size), pooled into a 201 bucket, and kept in the dark. Phytoplankton concentrates were analysed for chlorophyll a ( $\mathrm{chl}$ a) and, after calculations to provide an adequate amount of inocula, added to the mesocosms. Seawater (36 psu) collected from offshore Mangalore was ozonised (Ozone Generator-alt 11, Coren) and 9001 were added to each of the 9 cylindrical mesocosms that had a volume of $2000 \mathrm{l}$. The mesocosms were inoculated with either 2.651 of the plankton con- 
centrate, $150 \mathrm{ml}$ of the collected sediment, or both, with 3 replicates of each treatment as described below.

Light intensity was $50 \mu \mathrm{mol}$ photons $\mathrm{m}^{-2} \mathrm{~s}^{-1}$ at the water surface. Lamps were switched on during daytime to keep a 12:12 h light:dark cycle. The mesocosms were kept constantly aerated using plastic hoses connected to a pump. The inocula were added to the mesocosms in a random order. A mesocosm pilot study, carried out from 10 to 20 December 2005 with an identical set-up, revealed low phosphate concentrations $(0.02 \mu \mathrm{M})$. Since phosphate is normally not a limiting factor for primary production in the area (Krishnakumar \& Bhat 2007), phosphate was added daily to all 9 mesocosms until natural concentrations were reached (i.e. $0.5 \mu \mathrm{M}$, reached on Day 7 of the experiment).

The mesocosms were sampled every 2 to $3 \mathrm{~d}$ until chl a concentrations were stationary or declined. Every day, the mesocosms were stirred to mix the contents. During sampling, 2.51 were taken from the mesocosms using a ladle and were transferred to black, lightprotected bottles and immediately processed in the laboratory.

Inocula. The net tows were examined in an inverted microscope (Zeiss Axiovert 25) at 400× magnification to ensure that the plankton cells were in good condition, and that no larger zooplankton, i.e. copepods, were present. The plankton inoculum was designed to give a pre-phytoplankton bloom concentration of actively growing cells. No quantitative determination of the metabolic activity of the collected phytoplankton cells was made. The estimated chl a concentration after addition of the plankton concentrate was $0.9 \mu \mathrm{g}$ $\mathrm{l}^{-1}$, which is a low to moderate chl a concentration in the area (Krishnakumar \& Bhat 2007). To simulate the resuspension of $5 \mathrm{~mm}$ sediment and its even distribution through an average water-column depth of approximately $30 \mathrm{~m}$, we calculated the amount of sediment inoculum to add. In the mesocosms that were to receive sediment inocula, $150 \mathrm{ml}$ of surface sediment slurry were added.

Parameters analysed in mesocosms. All environmental parameters were sampled at each sampling occasion in all 9 mesocosms, i.e. every second or third day, except inorganic nitrate, ammonia and silicate, which were measured 4 times during the experimental period (Days 1, 6, 10 and 17).

The concentrations of inorganic nitrate, ammonia and silicate were monitored using Merck Spectroquant ${ }^{\circledR}$ kits (Merck) and a spectrophotometer (Spectroquant ${ }^{\circledR}$ NOVA 60, Merck). Phosphate was measured by the ascorbic acid method, and oxygen by Winkler titration (SS 028126, SS-EN 25 831). Temperature, salinity and $\mathrm{pH}$ were measured by thermometer, refractometer (Erma) and pH meter (MKVI Systronics). Total bacterial counts were estimated by DAPI staining of formalin-fixed samples (3\%) followed by epifluorescence microscopy, according to the protocol of Porter \& Feig (1980). Total viable bacteria counts (total plate count, TPC) were estimated by plating 10-fold dilutions of each sample on tryptone soya agar with $1 \%$ $\mathrm{NaCl}$ (TSAS) plates in duplicate. Enumeration of Vibrio spp. and $V$. parahaemolyticus was obtained by colony hybridisation. The alkaline phosphatase (AP)labelled probes 5'-XAA AGC GGA TTA TGC AGA AGC ACTG-3' (binding to the th gene encoding a thermolabile haemolysin present in all $V$. parahaemolyticus; McCarthy et al. 1999) and 5'-XTG TCA GGA AAA AGA TCC TGC ACT GTC TGA ACT-3' (Vibrio genus specific, binding to the gyrB gene; Raghunath et al. 2007) were purchased from DNA Technology. Colony hybridisation was carried out as described previously (Cook et al. 2000, Deepanjali et al. 2005, Raghunath et al. 2007). Briefly, each sample was diluted 1:10 and 1:100 in physiological saline. Then, $100 \mu \mathrm{l}$ each of undiluted sample as well as the 1:10 and 1:100 dilutions were spread on $\mathrm{T}_{1} \mathrm{~N}_{3}$ agar plates (1\% tryptone, $3 \% \mathrm{NaCl}, 2 \%$ agar; $\mathrm{pH} 7.4)$ in duplicate (only in single for the reference site samples) and incubated at $37^{\circ} \mathrm{C}$ overnight. Colony lifts were performed on plates with 100 to 1000 colonies onto Whatman No. 541 filter paper. Control strips containing 2 positive and 2 negative cultures were included in each hybridisation reaction. For enumeration of total Vibrio spp., V. parahaemolyticus (AQ 4037) and V. vulnificus (ATCC 27562) were used as positive controls; Salmonella enterica serovar Typhi (ATCC 12225) and Aeromonas hydrophila (laboratory isolate) were used as negative controls. For enumeration of $V$. parahaemolyticus, a $t d h^{+}, t r h^{-}$strain (obtained from the National Institute of Cholera and Enteric Diseases, Kolkata, India) and a $t d h^{+}, t r h^{-}$pandemic strain (SYO3:K6 isolated in our laboratory) were used as positive controls; V. vulnificus ATCC 27562 and $V$. cholerae ATCC 39315 were used as negative controls. The numbers of bluish grey or dark brown signals with colour intensity similar to that of the control strip were counted. Each signal represented a colony; the number of bacteria in the original sample was calculated by multiplying the number of positive signals by the dilution factor.

For estimations of chl a concentrations, $200 \mathrm{ml}$ from each sample were filtered onto GF/F filters. Chlorophyll was extracted in $7 \mathrm{ml}$ of $90 \%$ acetone and kept overnight at $4^{\circ} \mathrm{C}$. Of this, $1.5 \mathrm{ml}$ were centrifuged at $3655 \times g(10 \mathrm{~min})$, and the concentrations of the supernatants were measured on a spectrophotometer (Shimadzu). Chl a calculations were based on equations from Parsons et al. (1984).

For microscopic species identification and quantification of phytoplankton and potential grazers, $200 \mathrm{ml}$ 
of each sample were preserved with Lugol's solution and examined using an inverted light microscope (Zeiss Axiovert 25) at 200 to $400 \times$ magnification. Prior to microscopic analysis, samples of 10 or $50 \mathrm{ml}$ were settled overnight in sedimentation chambers (Utermöhl 1958). Species identification was based on the following literature: Subrahmanyan (1958), Subrahmanyan \& Sarma (1960), Thomsen (1992), Tomas (1997), and Throndsen et al. (2003).

Analysis of field samples from the reference site. Mangalore old port was used as a reference site. This location was sampled at the same time and frequency as the mesocosms. The parameters monitored were the same as for the mesocosm samples, as were the procedures. The only exception was that the surface water temperature was measured in situ.

Calculations and statistics. Partial least squares analysis: The relationship between the density of vibrio and physical, chemical and biological variables in the mesocosms was investigated with projection to latent structures by means of partial least squares analysis (PLS, Wold et al. 1984) using the software SIMCA-P 8.0 (UMETRICS). PLS is a regression based on latent variables and is used for finding the linear or polynomial relationship between a set of predictor variables $(x)$ and a set of response variables or a single response variable $(y)$. PLS has some advantages over multiple linear regression. PLS allows the number of predictor variables to be greater than that of the objects; it can use multitudes of correlated $x$ variables (multivariate collinear data); and it can tolerate certain amounts of missing data (Eriksson et al. 1999). The density of Vibrio spp. (colony-forming units [CFU] $1^{-1}$ ) in the mesocosms was used as the response variable $(y)$ in the model. Twelve different physical, chemical and biological parameters were used as predictor variables. Only the samples where data on all parameters were available were used in the PLS model (36 in all). All variables were $\log _{10}(x+1)$ transformed before analysis, and thereafter centred and scaled to unit variance.

Canonical correspondence analysis: Internal gradient analysis was used to examine the relationships between the density of vibrios, physical, chemical and biological factors, and the composition of phytoplankton species. Canonical correspondence analysis $(\mathrm{CCA}$; CANOCO version 4.5, Braak \& Smilauer 2002) was selected as the unimodal response model since the gradient was more than $2 \mathrm{SD}$. Two separate CCA were performed: 1 for the mesocosms and 1 for the reference site. The mesocosm CCA integrated several variables: vibrio density, 11 physical, chemical and biological variables, and 47 phytoplankton taxa having over $2 \%$ relative abundance. The type of inoculum (plankton, sediment or both) for each mesocosm was represented by nominal variables, which were coded by ' 0 ' for no addition or ' 1 ' for addition. The reference site CCA integrated 12 physical, chemical and biological variables (including vibrio density), and 26 phytoplankton taxa having over $2 \%$ relative abundance. None of the data were weighted. CCA was run constrained to each variable, i.e. density of vibrios, and the physical, chemical and biological variables were run in turn to determine the amount of variation that could be accounted for by that variable (axis 1 score). Sampling dates where all physical, chemical and biological data were available $(\mathrm{n}=36)$ were treated as active cases; the remaining sample dates $(n=27)$ were treated as supplementary samples. A Monte Carlo test was used to evaluate the significant relationship between density of vibrios, physical, chemical and biological variables, and phytoplankton species data. Significance of the CCA axes was tested by running 199 permutations.

\section{RESULTS}

Analyses were performed on samples collected at 8 occasions during $17 \mathrm{~d}$ from the 3 differet subsets of mesocosms: (1) 3 mesocosms with plankton, (2) 3 mesocosms with sediment, and (3) 3 mesocosms with both plankton and sediment, as well as from the reference site.

Physical variables. The physical variables salinity, temperature, $\mathrm{pH}$ and $\mathrm{O}_{2}$ showed only minor fluctuations in the mesocosms (Table 1). The oxygen concen-

Table 1. Range of environmental variables for all replicates of all mesocosm types and the reference site. TPC: total plate count

\begin{tabular}{|c|c|c|c|c|}
\hline Variable & Plankton & $\begin{array}{l}\text { Plankton+ } \\
\text { Sediment }\end{array}$ & Sediment & $\begin{array}{l}\text { Reference } \\
\text { site }\end{array}$ \\
\hline Salinity (PSU) & $34-38$ & $34-38$ & $34-38$ & $32-36$ \\
\hline Temperature $\left({ }^{\circ} \mathrm{C}\right)$ & $21-23.5$ & $21-23.5$ & $21-23.5$ & $23-24$ \\
\hline $\mathrm{pH}$ & $7.84-7.99$ & $7.74-8.02$ & $7.82-8.01$ & $7.78-7.97$ \\
\hline $\mathrm{O}_{2}\left(\mathrm{ml} \mathrm{l}^{-1}\right)$ & $6.26-7.88$ & $6.26-7.88$ & $6.26-7.88$ & $3.84-5.86$ \\
\hline $\mathrm{PO}_{4}(\mu \mathrm{M})$ & $0.02-0.53$ & $0.02-0.61$ & $0.02-0.57$ & $0.02-0.09$ \\
\hline $\mathrm{NH}_{4}(\mu \mathrm{M})$ & $11.1-105.56$ & $11.1-111.11$ & $11.1-94.44$ & $16.67-61.11$ \\
\hline $\mathrm{NO}_{3}(\mu \mathrm{M})$ & $11.29-19.36$ & $8.06-16.13$ & $9.67-17.74$ & $9.68-17.74$ \\
\hline $\mathrm{SiO}_{2}(\mu \mathrm{M})$ & $10.92-17.37$ & $9.61-22.89$ & $11.18-15.79$ & $9.93-24.47$ \\
\hline Vibrio $\left(10^{5} \mathrm{CFU} \mathrm{ml} \mathrm{m}^{-1}\right)$ & $0.0074-0.22$ & $0.0015-0.11$ & $0.0002-0.25$ & $0.003-0.58$ \\
\hline $\operatorname{TPC}\left(10^{5} \mathrm{CFU} \mathrm{ml}-1\right)$ & $0.0045-0.19$ & $0.0056-0.13$ & $0.0028-0.55$ & $0.014-0.67$ \\
\hline $\begin{array}{l}\text { Total bacteria } \\
\left(10^{5}{\left.\text { cells } \mathrm{ml}^{-1}\right)}^{-1}\right.\end{array}$ & $0.13-0.23$ & $2.3-5.9$ & $1.1-4.3$ & $0.48-1.8$ \\
\hline $\mathrm{Chl} a\left(\mu \mathrm{g} \mathrm{l}^{-1}\right)$ & $0.04-1.96$ & $0.67-1.83$ & $0.66-2.37$ & $1.67-4.87$ \\
\hline Flagellates (cells $1^{-1}$ ) & $0-4710$ & $0-66725$ & $0-51025$ & $0-23550$ \\
\hline
\end{tabular}


tration at the reference site was lower than in the mesocosms, probably due to the close proximity to the city of Mangalore and its effluents. Phosphate was added daily to the mesocosms until natural phosphate concentrations were attained on Day 7. Thereafter, the phosphate remained at the same concentrations in all mesocosms throughout the experiment. The ammonium concentration of the pre-sterilised water increased from 11 to ca. $100 \mu \mathrm{M}$ in all mesocosms. In comparing the lower end of the ranges of ammonium concentration, the reference site was comparable to the mesocosms (Table 1), but the highest concentration at the reference site $(61 \mu \mathrm{M})$ was somewhat lower than in the mesocosms. Nitrate and

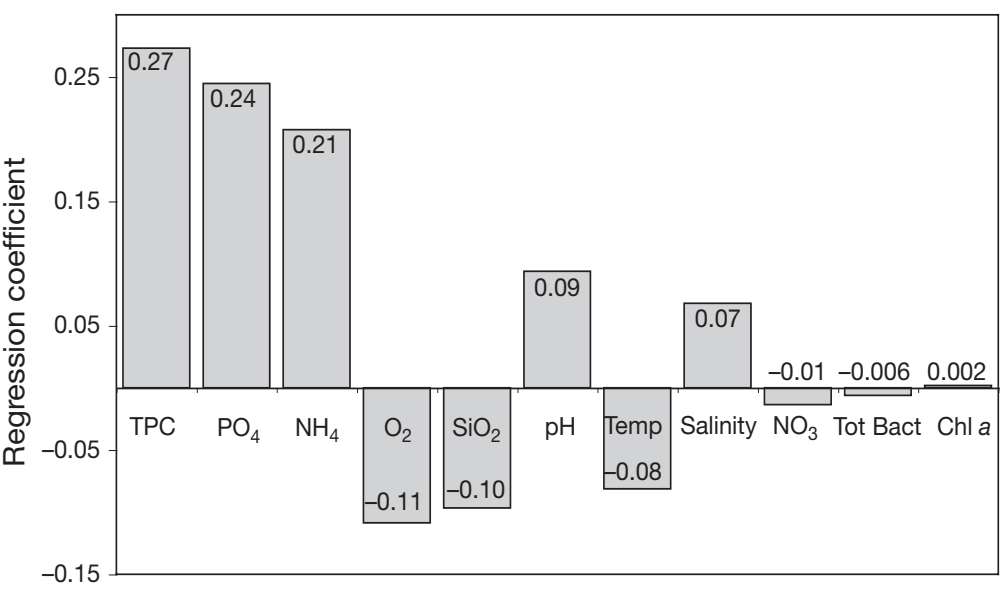
silicate concentrations were high in all meso-

Fig. 1. Partial least squares: variables tested in the model and their respective regression coefficients cosms and at the reference site throughout the experimental period. Maximum vibrio numbers were higher at the reference site compared to the mesocosms. The maximum TPC at the reference site was comparable to that in the sediment mesocosms, while it was lower in the plankton and plankton + sediment mesocosms. The total bacterial numbers reached the highest values in the sediment-inoculated mesocosms. The chl a concentration was comparable in all mesocosms, irrespective of inoculum, reaching a maximum of ca. $2 \mu \mathrm{g}^{-1}$. The corresponding concentrations were higher at the reference site. The maximum concentration of flagellates was highest in the sediment-inoculated mesocosms, lower at the reference site and lowest in the plankton mesocosms.

PLS. The PLS analysis was significant because the $\mathrm{Q}^{2}$ (cross-validated variance) statistics were larger than the limit (Table 2). The $\mathrm{Q}^{2}$ for a significant model or for a component should be larger than a critical value: $\mathrm{Q}^{2}$ limit $=0.097$, corresponding to $\mathrm{p}<0.05$. The 2-component model, where vibrio numbers constituted the response variable, explained $69.9 \%$ of the variation of vibrio numbers recorded in the mesocosms. The predicted fraction of the variation in vibrio numbers was $61.8 \%$; the higher percentage in the model sug-

Table 2. Model fitting results of partial least squares (PLS) analysis on physical, chemical and biological predictor variables $(x)$, and Vibrio numbers as the response variable $(y)$ in the mesocosms. k: component number; $\mathrm{R}^{2} x(\mathrm{cum})$ : cumulative fraction of sum of squares of all $x^{\prime}$ s explained by the components; $R^{2} y$ (cum): cumulative fraction of sum of squares of all $y^{\prime}$ s explained by the components

\begin{tabular}{|lccccc|}
\hline Model & $\mathrm{k}$ & Eigenvalue & $\mathrm{R}^{2} X(\mathrm{cum})$ & $\mathrm{R}^{2} y($ cum $)$ & $\mathrm{Q}^{2}$ (cum) \\
\hline PLS-Vibrio & 1 & 2.95 & 0.227 & 0.608 & 0.553 \\
& 2 & 4.21 & 0.551 & 0.699 & 0.618 \\
\hline
\end{tabular}

gests it is a good model. The variables tested in the model, and their respective regression coefficients, are depicted graphically in Fig. 1. The principal environmental variable positively influencing vibrio numbers was TPC. This was tightly followed by the nutrients phosphate and ammonium. Oxygen, silica and temperature were negatively related to vibrios, whereas salinity and $\mathrm{pH}$ were positively correlated. According to the model, nitrate, total bacteria and chl a were not influential, displaying regression coefficients close to 0 (Fig. 1).

Phytoplankon and bacteria in mesocosms. Diatoms were the dominant group of phytoplankton, constituting $>90 \%$ of the phytoplankton assemblages in all mesocosms throughout the experimental period. The highest diatom abundances (Days 6 and 13) were followed by an increase in Vibrio spp. in all mesocosms, irrespective of inoculum (Fig. 2). The maximum diatom cell densities recorded on Day 6, i.e. approximately 215000 cells $\mathrm{l}^{-1}$, originated from the plankton inoculum, while the high abundances on Day 13 (ca. 125000 cells $\mathrm{l}^{-1}$ ) were a consequence of germinated diatom resting stages from the sediment (Fig. 2A, Härnström et al. 2007). On Days 8 to 10, high numbers of vibrio cells were recorded (up to $15000 \mathrm{CFU} \mathrm{ml}^{-1}$ ), and numbers of the same range were documented on Day 17, i.e. at the very end of the experiment (Fig. 2B).

The 2 inoculum types contained $<1000$ Vibrio spp. $\mathrm{CFU} \mathrm{ml} \mathrm{m}^{-1}$ at the start of the experiment, with slightly higher numbers in the plankton than in the sediment inoculum (Fig. 2B). From Day 1, the vibrio numbers increased in all mesocosms. Growth was fastest in the sediment mesocosms, reaching approximately $7500 \mathrm{CFU} \mathrm{ml} \mathrm{m}^{-1}$ on Day 6, while the mesocosms with plankton and with plankton + sediment peaked on Day 8 (ca. 9500 CFU ml $^{-1}$ ) and on Day 10 (ca. 6500 CFU $\mathrm{ml}^{-1}$ ), respectively. On Day 13, the numbers of vibrios 


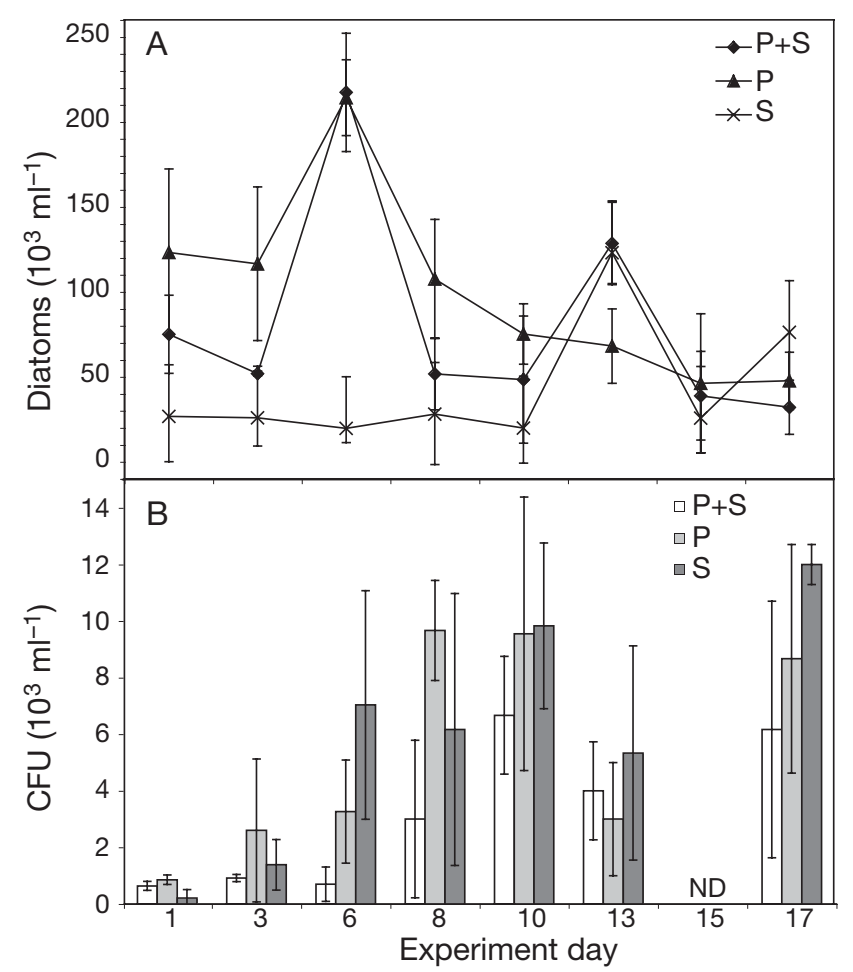

Fig. 2. (A) Diatom cell abundance in mesocosms. (B) Vibrio spp. colony-forming units (CFU) in mesocosms. P + S: plankton + sediment, P: plankton, S: sediment. Error bars represent $\mathrm{SD}$ for triplicate mesocosms for each treatment; ND: not determined

decreased in all mesocosms, regardless of inoculum, to approximately $4000 \mathrm{CFU} \mathrm{ml} \mathrm{Cl}^{-1}$. Four days later, the recorded vibrio numbers had increased in all mesocosms (ranging from 6500 to $12000 \mathrm{CFU} \mathrm{ml}^{-1}$ ). The vibrio population did not dominate the total bacterial community in the mesocosms. The highest proportion of vibrios was attained in the plankton mesocosms, reaching $14 \%$ on Day 10 (Table 3). A much lower proportion was observed in the plankton + sediment and the sediment mesocosms ( 0.1 to $2.8 \%$ ). Vibrio spp. constituted a considerable part of the total bacterial plate counts (TPC), and the Vibrio spp.: TPC ratio increased in general in all mesocosms (Table 3). The initial numbers of $V$. parahaemolyticus were low (ca. $200 \mathrm{CFU}$ $\mathrm{ml}^{-1}$ ) in all mesocosms (data not shown). This species' contribution to the total vibrio population fluctuated considerably. On Day 6 of the experiment, V. parahaemolyticus was at comparable CFU numbers in all mesocosms, and the numbers increased until the end of the experiment. The contribution of $V$. parahaemolyticus to the whole bacterial community was low $(0.007$ to $4.3 \%)$, but constituted a rather high proportion of the vibrio community in the system (up to $81 \%$ in the plankton + sediment mesocosm on Day 6 , Table 3).
Phytoplankon and vibrios at the reference site. At the reference site, the plankton community was dominated by diatoms, representing 55 to $82 \%$ of the total phytoplankton assemblage. Maximum diatom abundance (571000 diatoms $\mathrm{l}^{-1}$ ) was recorded on Day 6, and was followed by high numbers of vibrio cells (58000 CFU ml-1) on Day 8 (Fig. 3). On this day, the vibrio population dominated the bacterial community in the water $(70 \%$, Table 3$)$. A high abundance of diatoms was also recorded on Day 13 (470000 cells $\mathrm{l}^{-1}$ ). This second diatom peak was not followed by a significant increase in vibrio abundance (25000 CFU ml-1), but the vibrio population was still a significant part of the total bacterial plate counts (Table 3).

Vibrio parahaemolyticus constituted a significant part of the total vibrio population $(66.7 \%)$ on Day 1 (Table 3). After the first sampling days, the proportion of $V$. parahaemolyticus quickly declined and remained at low levels (1.1 to $5.6 \%$ of the total vibrio population) for the rest of the period.

CCA of mesocosms. The CCAs were significant, both for the mesocosm data and for the reference site ( $p=0.005$, Monte Carlo). For the mesocosm CCA, eigenvalues of axes $1\left(\lambda_{1}=0.33\right), 2\left(\lambda_{2}=0.14\right), 3\left(\lambda_{3}=\right.$ $0.10)$ and $4\left(\lambda_{4}=0.07\right)$ explained $21.4 \%$ of the cumulative variance in species data, and $70.7 \%$ of the relation between species and environmental data (Table 4). The ranks of the environmental variables contributing to this model were (1) sediment, (2) phosphate, (3) total bacteria, (4) chl a, (5) plankton, (6) temperature, (7) salinity, (8) $\mathrm{pH}$, (9) total plate count, (10) oxygen, (11) vibrios, (12) nitrate, (13) silicate and (14) ammonia.

The CCA for the mesocosms showed high correlations between $\mathrm{SiO}_{2}$ and $\mathrm{NO}_{3}$, and between $\mathrm{pH}$, temperature and salinity, whereas the correlations between the other variables were moderate to low (Table 5). The values of the inflation factors (VIF) were low $(<8)$ for all environmental variables except for $\mathrm{pH}$, salinity and temperature. VIF is related to the multiple correlations among the environmental variables, and values $<20$ suggest that the environmental parameters add new information to the analysis. The species-environmental correlations for axes 1 (0.89), 2 (0.78), 3 (0.69) and 4 (0.81) were high. Based on interset correlations, sediment had the strongest association to axis 1, phosphate to axes 2 and 3, and chl a to axis 4 (Table 4). Vibrio abundances, inoculum types, and physical, chemical and biological variables appear in the CCA biplot as arrows; their length and orientation indicate their relative importance to each axis (Fig. 4). All arrows represent a gradient, where the mean value is located at the origin, and the arrow points in the direction of its increase. Vibrios were closely coupled to TPC and phosphate (Fig. 4). The arrow that represents oxygen points in the opposite direction to vibrios. The positions 
Table 3. Vibrio spp. and V. parahaemolyticus (V.p.) ratios compared to total bacterial (tot. bact.) counts and total plate counts (TPC). ND: not determined

\begin{tabular}{|c|c|c|c|c|c|}
\hline Day & $\begin{array}{l}\text { Vibrio/tot. } \\
\text { bact. (\%) }\end{array}$ & $\begin{array}{c}\text { Vibrio/TPC } \\
(\%)\end{array}$ & $\begin{array}{l}\text { V.p./tot. } \\
\text { bact. (\%) }\end{array}$ & $\begin{array}{c}V . p . / \mathrm{TPC} \\
(\%)\end{array}$ & $\begin{array}{c}\text { V.p./vibrios } \\
(\%)\end{array}$ \\
\hline \multicolumn{6}{|c|}{ Plankton+sediment } \\
\hline 1 & 0.3 & 5 & 0,04 & 0.8 & 15.7 \\
\hline 3 & 0.2 & 7.2 & 0.007 & 0.3 & 3.6 \\
\hline 6 & 0.1 & 5.4 & 0.1 & 4.4 & 81 \\
\hline 8 & 0.5 & 20.9 & 0.08 & 3.1 & 15 \\
\hline 10 & 1.7 & 43.5 & 0.3 & 7.6 & 17.5 \\
\hline 13 & 1.3 & 27.9 & 0.4 & 8.6 & 30.8 \\
\hline 17 & 2.1 & 38.6 & 0.5 & 8.5 & 22.2 \\
\hline \multicolumn{6}{|c|}{ Plankton } \\
\hline 1 & 2.4 & 6.7 & 0.6 & 1.7 & 25.3 \\
\hline 3 & 3.9 & 18.4 & 0.1 & 0.7 & 3.8 \\
\hline 6 & 3.1 & 23.1 & 0.7 & 5.1 & 21.9 \\
\hline 8 & 9.8 & 49.9 & 0.5 & 2.8 & 5.5 \\
\hline 10 & 14.2 & 55.5 & 1.6 & 6.2 & 11.2 \\
\hline 13 & 10.2 & 21.3 & 4.3 & 8.5 & 40 \\
\hline 17 & 5.1 & 52 & 0.3 & 5.2 & 5.2 \\
\hline \multicolumn{6}{|c|}{ Sediment } \\
\hline 1 & 0.1 & 8.5 & ND & ND & ND \\
\hline 3 & 0.5 & 6.4 & 0.05 & 0.7 & 10.8 \\
\hline 6 & 2.5 & 58.9 & 0.3 & 6.4 & 10.9 \\
\hline 8 & 2.0 & 68.9 & 0.4 & 13.8 & 20 \\
\hline 10 & 2.8 & 67.7 & 0.3 & 6.7 & 9,8 \\
\hline 13 & 1.8 & 47.1 & 0.3 & 8.2 & 17.5 \\
\hline 17 & 0.5 & 37.3 & 0.03 & 2.5 & 6.7 \\
\hline \multicolumn{6}{|c|}{ Reference site } \\
\hline 1 & 0.4 & 21.4 & 0.2 & 14.3 & 66.7 \\
\hline 3 & 1.7 & 10.8 & 0.4 & 2.7 & 25 \\
\hline 6 & 7.7 & 34.4 & 0.2 & 0.8 & 2.3 \\
\hline 8 & 70 & 86.6 & 0.8 & 1 & 1,1 \\
\hline 10 & 22 & 63.8 & 1 & 6.4 & 5.6 \\
\hline 13 & 13 & 84 & 0.4 & 3 & 3.6 \\
\hline 17 & 13 & 63.9 & 0.4 & 1.8 & 2.8 \\
\hline
\end{tabular}

of the different phytoplankton taxa are strongly dependent on inoculum type (plankton or sediment) in contrast to vibrios that do not have an apparent affinity to any specific inoculum type. The diatom genus Coscinodiscus appears to be positively related to Vibrio spp., whereas the genera Chaetoceros and Skeletonema were negatively related. Flagellates showed a strong correlation to Vibrio spp. and TPC.

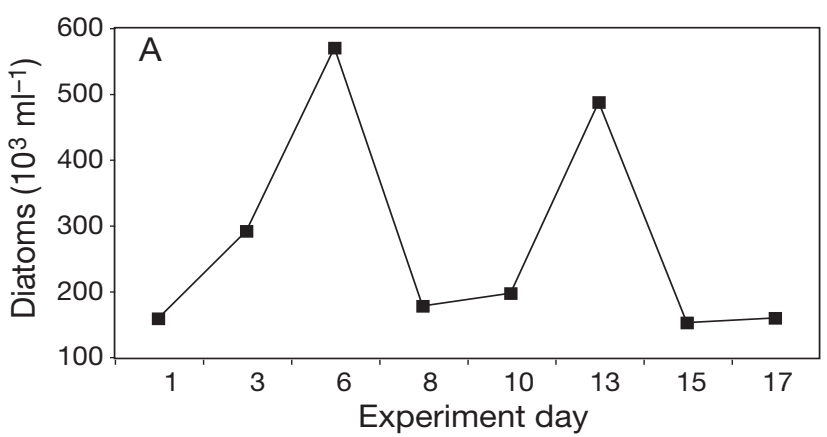

CCA of the reference site. For the reference site CCA, eigenvalues of axes $1\left(\lambda_{1}=0.43\right), 2\left(\lambda_{2}=0.32\right), 3\left(\lambda_{3}=\right.$ $0.21)$ and $4\left(\lambda_{4}=0.20\right)$ explained $90.1 \%$ of the cumulative variance in species data, and $90.1 \%$ of the relation between species and environmental data (Table 6). The ranks of the environmental variables contributing to this model were (1) $\mathrm{pH}$, temperature and salinity, (2) chl $a$, (3) phosphate, (4) nitrate and silicate, (5) total bacteria, (6) ammonia, (7) TPC, (8) vibrios and (9) oxygen.

The CCA for the reference site showed high correlations between $\mathrm{SiO}_{2}$ and $\mathrm{NO}_{3}$, between $\mathrm{pH}$, temperature and salinity, and between vibrios and TPC, whereas the correlations between the other environmental variables were moderate to low (Table 7). VIFs were low $(<20)$ for all environmental variables except nitrate. The species-environmental correlations for axes 1 to 4 were 1.0. Based on interset correlations, salinity, $\mathrm{pH}$ and temperature had the strongest ties to axis 1, chl a to axis 2, total bacteria to axis 3, and salinity to axis 4 .

Vibrios were closely coupled to TPC (Table 7), but there was no correlation between vibrios and total bacteria (Table 6, Fig. 5). The diatom genus Chaetoceros was negatively related to Vibrio spp., and flagellates showed a strong affinity to Vibrio spp.

\section{DISCUSSION}

Many studies have shown that vibrios are ubiquitous in marine and brackish waters. As bacterioplankton, they usually constitute $<1 \%$ of the population, but under some conditions they can increase and totally

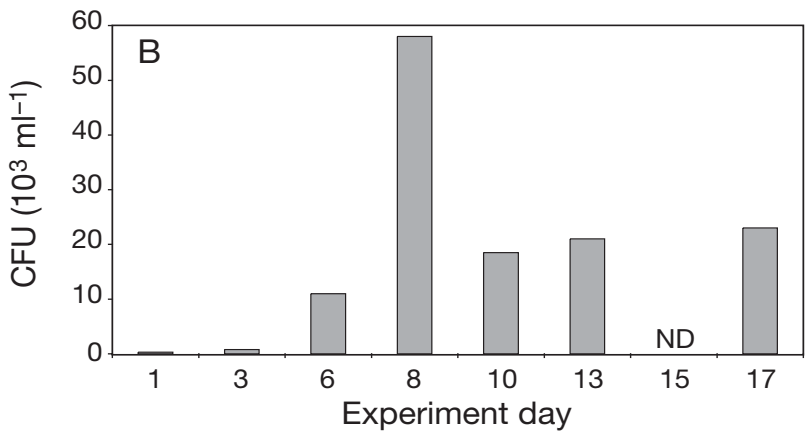

Fig. 3. (A) Diatom cell abundance at the reference site. (B) Vibrio spp. colony-forming units (CFU) at the reference site. ND: not determined 
Table 4. Interset correlations of environmental variables with axes from mesocosm data. $\lambda$ represents eigenvalue for each axis. Tot.: total; TPC: total plate count

\begin{tabular}{|lcrrr|}
\hline Variable & $\begin{array}{c}\text { Axis 1 } \\
(\lambda=0.334)\end{array}$ & $\begin{array}{c}\text { Axis 2 } \\
(\lambda=0.142)\end{array}$ & $\begin{array}{c}\text { Axis 3 } \\
(\lambda=0.098)\end{array}$ & $\begin{array}{c}\text { Axis 4 } \\
(\lambda=0.073)\end{array}$ \\
\hline $\mathrm{Chl} a$ & -0.422 & -0.188 & 0.036 & -0.286 \\
$\mathrm{PO}_{4}$ & -0.579 & 0.359 & 0.320 & -0.048 \\
$\mathrm{NH}_{4}$ & -0.47 & 0.284 & 0.043 & -0.094 \\
$\mathrm{NO}_{3}$ & 0.120 & 0.236 & -0.228 & 0.083 \\
$\mathrm{SiO}_{2}$ & 0.069 & 0.133 & -0.250 & 0.200 \\
$\mathrm{O}_{2}$ & 0.258 & -0.052 & -0.058 & -0.233 \\
$\mathrm{Salinity}$ & 0.231 & -0.329 & 0.104 & 0.114 \\
$\mathrm{pH}$ & 0.245 & -0.331 & 0.094 & 0.069 \\
Temperature & 0.258 & -0.354 & 0.089 & 0.082 \\
Vibrio & -0.259 & 0.059 & 0.307 & 0.143 \\
Tot. bacteria & -0.611 & -0.109 & -0.124 & -0.229 \\
TPC & -0.269 & 0.123 & -0.248 & 0.153 \\
Plankton & 0.413 & 0.089 & -0.182 & -0.114 \\
Sediment & -0.828 & -0.105 & -0.136 & -0.077 \\
\hline
\end{tabular}

dominate for short periods, as part of a marine bacterial succession pattern (Rehnstam et al. 1993). In this study, we observed a bloom of vibrio at the reference site. At the beginning of the sampling period, vibrios made up only $0.4 \%$ of the total bacterial community (Fig. 3B, Table 3). By Day 8, they had increased to $70 \%$, and by the end of the sampling period, the proportion was $13 \%$. A similar strong increase in vibrio numbers was not observed in the mesocosms (Fig. 2B). In the sediment-containing mesocosms, the vibrio abundance increased from 0.1 to $2.8 \%$ of total bacterial counts (Table 3). In the mesocosms inoculated with plankton only, the vibrio abundance constituted a significantly higher percentage of the total bacterial abundance, i.e. up to $14 \%$. Vibrio abundance has previously been documented to fluctuate considerably depending on geographical region and time of the year. One of the lowest, 0.002 to $0.015 \%$, has been recorded in the Baltic Sea using culture-independent quantitative competitive PCR (Eiler et al. 2006), and the highest, $68 \%$, on the Japanese coast was detected by culture-dependent techniques (Simidu \& Tsukamoto 1980).

Vibrios can be found, but are seldom dominant, in marine sediments (Oliver et al. 1982, Maeda et al. 2003). Indeed, the facultative anaerobic growth of vibrios suggests a possible commensal role in mediating organic matter decomposition. In Indian waters, high levels of organic matter near shrimp farms have been shown to give elevated levels of Vibrio spp. (Otta et al. 1999). Our experiment showed that vibrios, in general, had no specific affinity to sediment or plankton, which implies that they could be associated with (and be sustained by) organic matter from both phytoplankton and sediment. However, the vibrio population was slightly more favoured in the plankton mesocosms (without sediment) compared to other bacteria (Table 3). This can be explained as less competition from sediment bacteria for nutrients, few Vibrio spp.-specific bacteriophages, or low levels of predation in sedimentfree mesocosms, as indicated by lower numbers of flagellates in the plankton-inoculated mesocosms (Table 1). The proportion of $V$. parahaemolyticus among total bacterial plate counts increased slightly in the mesocosms during the study period. V. parahaemolyticus has been reported to exhibit a seasonal migration pattern in temperate areas, alternating between zooplankton in summer and sediment in winter (Kaneko \& Colwell 1973). Low variation in vibrio abundance in ocean waters has been reported from other parts of the world (Oliver et al. 1982, Chan et al. 1986). V. parahaemolyticus represented about 0.2 to

Table 5. Correlations among environmental and nominal variables used in canonical correspondence analysis for mesocosms. Tot. bact.: total bacteria; TPC: total plate count

\begin{tabular}{|c|c|c|c|c|c|c|c|c|c|c|c|c|c|c|}
\hline Variables & Chl a & $\mathrm{PO}_{4}$ & $\mathrm{NH}_{4}$ & $\mathrm{NO}_{3}$ & $\mathrm{SiO}_{2}$ & $\mathrm{O}_{2}$ & Salinity & $\mathrm{pH}$ & Temp & Vibrio & Tot. bact. & TPC & Plankton & Sediment \\
\hline Chl a & 1.00 & & & & & & & & & & & & & \\
\hline $\mathrm{PO}_{4}$ & 0.32 & 1.00 & & & & & & & & & & & & \\
\hline $\mathrm{NH}_{4}$ & -0.09 & 0.07 & 1.00 & & & & & & & & & & & \\
\hline $\mathrm{NO}_{3}$ & -0.09 & -0.26 & 0.62 & 1.00 & & & & & & & & & & \\
\hline $\mathrm{SiO}_{2}$ & -0.10 & -0.32 & 0.55 & 0.90 & 1.00 & & & & & & & & & \\
\hline $\mathrm{O}_{2}$ & 0.16 & -0.38 & 0.07 & 0.29 & 0.23 & 1.00 & & & & & & & & \\
\hline Salinity & 0.01 & -0.53 & 0.34 & 0.51 & 0.52 & 0.37 & 1.00 & & & & & & & \\
\hline $\mathrm{pH}$ & 0.03 & -0.54 & 0.34 & 0.52 & 0.53 & 0.41 & 1.00 & 1.00 & & & & & & \\
\hline Temp & 0.02 & -0.56 & 0.32 & 0.50 & 0.52 & 0.40 & 1.00 & 1.00 & 1.00 & & & & & \\
\hline Vibrio & -0.06 & 0.43 & 0.27 & 0.00 & -0.07 & -0.22 & -0.07 & -0.09 & -0.11 & 1.00 & & & & \\
\hline Tot. bact. & 0.06 & 0.33 & 0.00 & 0.07 & 0.07 & 0.27 & -0.02 & 0.00 & -0.01 & -0.08 & 1.00 & & & \\
\hline TPC & 0.01 & 0.39 & 0.19 & -0.13 & -0.17 & -0.37 & -0.12 & -0.15 & -0.16 & 0.69 & -0.13 & 1.00 & & \\
\hline Plankton & -0.02 & -0.31 & 0.05 & 0.22 & 0.19 & 0.33 & 0.17 & 0.18 & 0.19 & -0.30 & -0.05 & -0.47 & 1.00 & \\
\hline Sediment & 0.49 & 0.46 & -0.07 & -0.13 & -0.06 & -0.11 & -0.21 & -0.21 & -0.22 & 0.06 & 0.78 & 0.12 & -0.37 & 1.00 \\
\hline
\end{tabular}




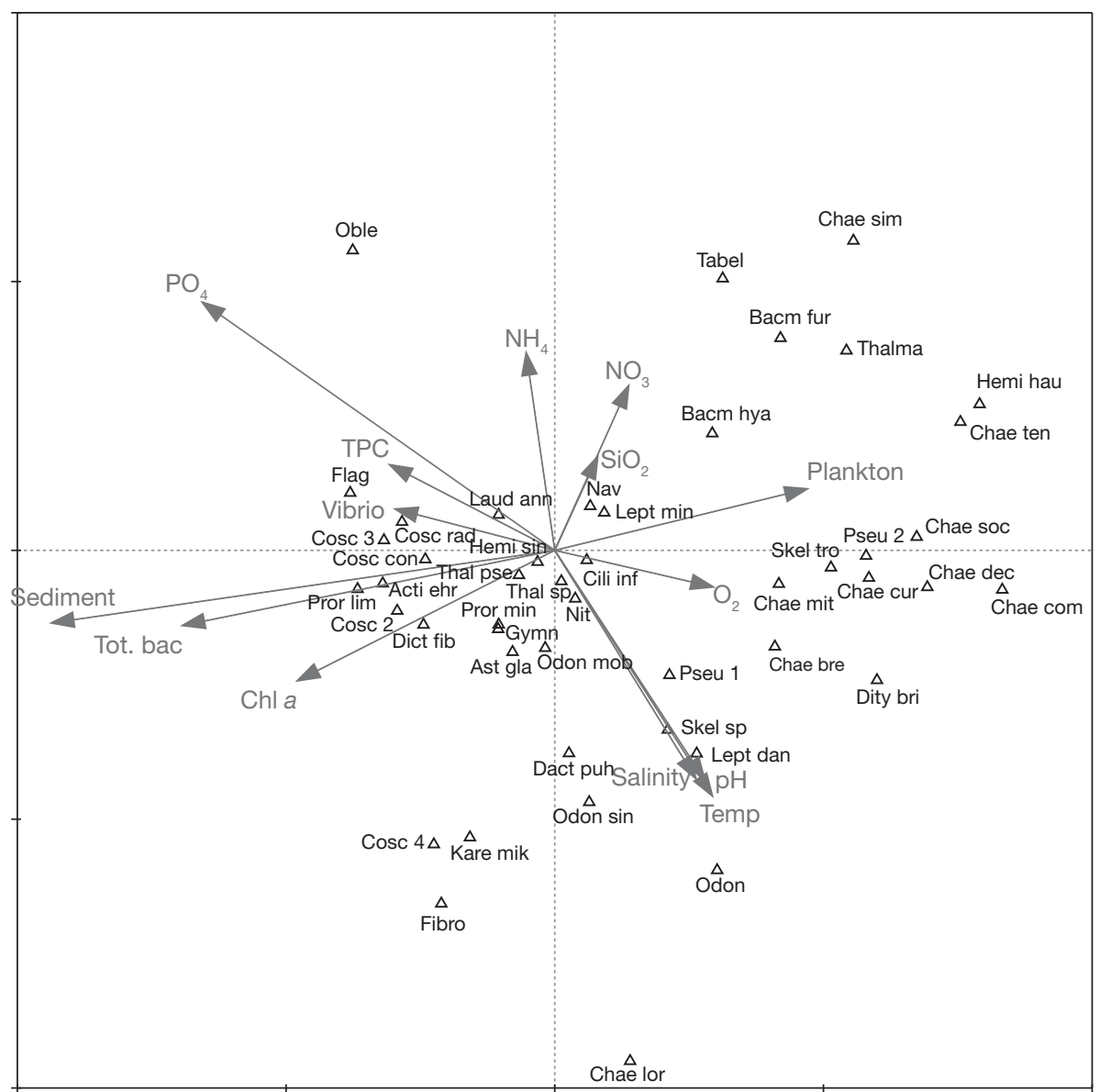

Fig. 4. Canonical correspondence analysis biplots for algal species abundance in mesocosms and environmental variables. Acti ehr $=$ Actionocyclus ehrenbergii, Ast gla $=$ Asterionellopsis glacialis, Bacm fur $=$ Bacteriastrum furcatum, Bacm hya $=$ Bacteriastrum hyalinum, Cili inf $=$ Ciliophrys infusionum, Chae bre $=$ Chaetoceros brevis, Chae com $=$ C. compressus, Chae cur $=$ C. curvicetus, Chae dec $=C$. decipiens, Chae lor $=C$. lorenzianus, Chae mit $=C$. mitra, Chae sim $=C$. simplex, Chae soc $=C$. socialis, Chae ten $=$ C. tenuissimus, Cosc con $=$ Coscinodiscus concinnus, Cosc $2=$ Coscinodiscus sp. 2 , Cosc $3=$ Coscinodiscus sp. 3 , Cosc $4=$ Coscinodiscus sp. 4, Cosc rad $=$ C. radiatus, Dact puh $=$ Dactyliosolen phuketensis, Dict fib = Dictyocha fibula, Dity bri $=$ Ditylum brightwelli, Fibro = Fibrocapsa sp., Flag = Unidentified flagellates, Gymn = Gymnodinium sp., Hemi hau = Hemiaulus haukii, Hemi $\sin =H$. sinensis, Kare mik = Karenina mikimotoi, Laud ann = Lauderia annulata, Lept dan = Leptocylindrus danicus, Lept min $=$ L. minimus, Nav = Navicula sp., Nit = Nitzschia sp., Oble = Oblea sp., Odon mob = Odontella mobiliensis, Odon $=$ Odontella sp., Odon $\sin =O$. sinensis, Pror lim = Prorocentrum lima, Pror min $=$ P. minimum, Pseu $1=$ Pseudo-nitzschia sp. 1 , Pseu $2=$ Pseudo-nitzschia sp. 2, Skel sp = Skeletonema sp., Skel tro = S. tropicum, Tabel = Tabellaria sp., Thalma = Thalassionema nitzschioides, Thal pse $=$ Thalassiosira pseudonana, Thal $\mathrm{sp}=$ Thalassiosira $\mathrm{sp}$.

$1 \%$ of the total bacterial community at our reference site (Table 3). However, the relative proportion of $V$. parahaemolyticus decreased considerably from approximately $67 \%$ of the total vibrio population on Day 1 to ca. $2 \%$ at the end of the sampling.

Mass occurrence of phytoplankton, measured as chl $a$, has been known to indirectly contribute to vibrio growth (Lobitz et al. 2000). In the present study, chl a showed a weak but positive correlation to total bacterial counts, but not to vibrios or other colony-forming bacteria. Instead, our results clearly showed that peaks in vibrios and other colony-forming bacteria are preceded by elevated numbers of diatoms (Figs. 2 \& 3).
In most studies concerned with algal blooms and bacterial biomass increase, a similar distinct delay is observed between the bloom of phytoplankton and the peak of bacterial abundance, at timescales of 3 to $14 \mathrm{~d}$ in coastal waters (Jonas \& Tuttle 1990, Smith et al. 1995). In our mesocosm experimental system, diatom blooms reached maxima on Days 6 and 13, and vibrio peaked on Days 8 to 10 and 17, a delay of 2 to $4 \mathrm{~d}$. This pattern was also observed at the reference site, verifying the coupling of the blooms and validating the mesocosms as a model of the natural environment. The difference in time scale between this and other studies may be due to different temperatures; tropical condi- 
Table 6. Interset correlations of environmental variables with axes from reference site data. $\lambda$ represents eigenvalue for each axis. Tot.: totali TPC: total plate count

\begin{tabular}{|lcrrr|}
\hline Variable & $\begin{array}{c}\text { Axis 1 } \\
(\lambda=0.425)\end{array}$ & $\begin{array}{c}\text { Axis 2 } \\
(\lambda=0.317)\end{array}$ & $\begin{array}{c}\text { Axis 3 } \\
\lambda=0.211)\end{array}$ & $\begin{array}{c}\text { Axis 4 } \\
(\lambda=0.197)\end{array}$ \\
\hline $\mathrm{Chl} a$ & -0.601 & 0.707 & 0.308 & 0.163 \\
$\mathrm{PO}_{4}$ & -0.555 & -0.205 & -0.556 & -0.557 \\
$\mathrm{NH}_{4}$ & -0.283 & -0.345 & -0.203 & 0.374 \\
$\mathrm{NO}_{3}$ & -0.552 & -0.496 & -0.458 & -0.087 \\
$\mathrm{SiO}_{2}$ & -0.514 & -0.617 & -0.185 & -0.013 \\
$\mathrm{O}_{2}$ & -0.192 & -0.136 & 0.039 & 0.086 \\
$\mathrm{Salinity}$ & -0.880 & 0.060 & 0.081 & 0.457 \\
pH & -0.914 & -0.005 & 0.060 & 0.391 \\
Temperature & -0.902 & 0.003 & 0.096 & 0.405 \\
Vibrio & -0.081 & -0.299 & 0.263 & -0.225 \\
Tot. bacteria & -0.026 & 0.200 & -0.588 & -0.432 \\
TPC & -0.215 & -0.330 & 0.100 & -0.385 \\
\hline
\end{tabular}

tions would favour rapid bacterial growth. Diatoms are regarded as especially important for the growth of vibrios and other colony-forming marine bacteria with exoenzyme activities (Smith et al. 1995, Salvesen et al. 2000). An increase in vibrio numbers as the diatom populations decline is suggestive of vibrios growing on decaying planktonic cells. However, some of the diatoms recorded in the present study, such as Chaetoceros brevis, C. socialis, and C. simplex, are known to have inhibitory effects on Vibrio spp. (Viso et al. 1987, Naviner et al. 1999). Other potential inhibitory diatoms include some members of the genus Skeletonema. We found that all Chaetoceros species that we identified in this study were negatively correlated to vibrios (Figs. 4 \& 5), both in the mesocosms and at the reference site. We have also observed that Vibrio cultures can change from cultivable into a viable but non-cultivable state when co-cultured with $S$. marinoi (A. S. RehnstamHolm et al. unpubl. results). However, the nature of the algal inhibitory effect still remains to be elucidated. Other studies have shown strong correlations between vibrio abundance and dinoflagellates, including potentially toxic species like Gymnodinium, Dinophysis, and Prorocentrum (Islam et al. 1994, Mouriño-Pérez et al. 2003, Eiler et al. 2006). This could not be supported in our study due to very low dinoflagellate numbers throughout the entire experimental period.

The 2 most important environmental factors associated with high abundances of vibrios, especially Vibrio cholerae, are low salinity and high water temperature. There are repeated reports that these factors control vibrio abundance in the marine environment and that they can be used on large scales for the prediction of $V$. cholerae-related outbreaks in endemic areas (Lobitz et al. 2000). In accordance, salinity is an important ecological factor in estuarine waters around Mangalore (Deepanjali et al. 2005). However, the occurrence of Vibrio spp. is not attributable only to temperature and salinity. Thus, it is important to determine other, less obvious relationships between vibrios and components of marine coastal waters. It is usually understood that vibrio proliferation is determined by a combination of top-down predation by flagellates and viruses and bottom-up control of nutrients, salinity and temperature. Reductions in predation or increased nutrient levels have been reported as important factors contributing to explosive growth of vibrios in experimental systems (Eilers et al. 2000, Pinhassi \& Berman 2003). The results from our experimental mesocosm system indicate a positive coupling of vibrios to phosphorus and ammonia, and a negative coupling to oxygen levels and silica. These findings are not surprising, since vibrios have a heterotrophic mode of metabolism. The negative correlation between $\mathrm{SiO}_{2}$ concentration and vibrio abundance is probably a consequence of the diatom 'blooms' (which consume $\mathrm{SiO}_{2}$ ) preceding the vibrios.

Table 7. Correlation among environmental variables used in canonical correspondence analysis for the reference site. Tot. bact.: total bacteria; TPC: total plate count

\begin{tabular}{|c|c|c|c|c|c|c|c|c|c|c|c|}
\hline Variables & $\mathrm{Chl} \mathrm{a}$ & $\mathrm{PO}_{4}$ & $\mathrm{NH}_{4}$ & $\mathrm{NO}_{3}$ & $\mathrm{SiO}_{2}$ & $\mathrm{O}_{2}$ & Salinity & $\mathrm{pH}$ & Temp & Vibrio & Tot. bact. \\
\hline Chl a & 1.00 & & & & & & & & & & \\
\hline $\mathrm{PO}_{4}$ & -0.07 & 1.00 & & & & & & & & & \\
\hline $\mathrm{NH}_{4}$ & -0.16 & 0.04 & 1.00 & & & & & & & & \\
\hline $\mathrm{NO}_{3}$ & -0.18 & 0.76 & 0.33 & 1.00 & & & & & & & \\
\hline $\mathrm{SiO}_{2}$ & -0.19 & 0.58 & 0.30 & $0.95^{\mathrm{a}}$ & 1.00 & & & & & & \\
\hline $\mathrm{O}_{2}$ & 0.00 & 0.02 & 0.33 & -0.26 & -0.30 & 1.00 & & & & & \\
\hline Salinity & 0.68 & 0.17 & 0.38 & 0.39 & 0.41 & 0.14 & 1.00 & & & & \\
\hline $\mathrm{pH}$ & 0.63 & 0.25 & 0.39 & 0.46 & 0.48 & 0.14 & $0.99^{a}$ & 1.00 & & & \\
\hline Temp & 0.65 & 0.21 & 0.37 & 0.44 & 0.47 & 0.12 & $1.00^{\mathrm{a}}$ & $1.00^{\mathrm{a}}$ & 1.00 & & \\
\hline Vibrio & -0.31 & -0.09 & 0.53 & -0.23 & -0.19 & 0.65 & -0.21 & -0.19 & -0.20 & 1.00 & \\
\hline Tot. bact. & -0.13 & 0.52 & -0.06 & 0.48 & 0.30 & -0.67 & -0.22 & -0.19 & -0.20 & -0.35 & 1.00 \\
\hline ТPC & -0.23 & 0.30 & 0.52 & 0.09 & 0.08 & 0.65 & -0.04 & 0.00 & -0.02 & $0.91^{\mathrm{a}}$ & -0.18 \\
\hline
\end{tabular}




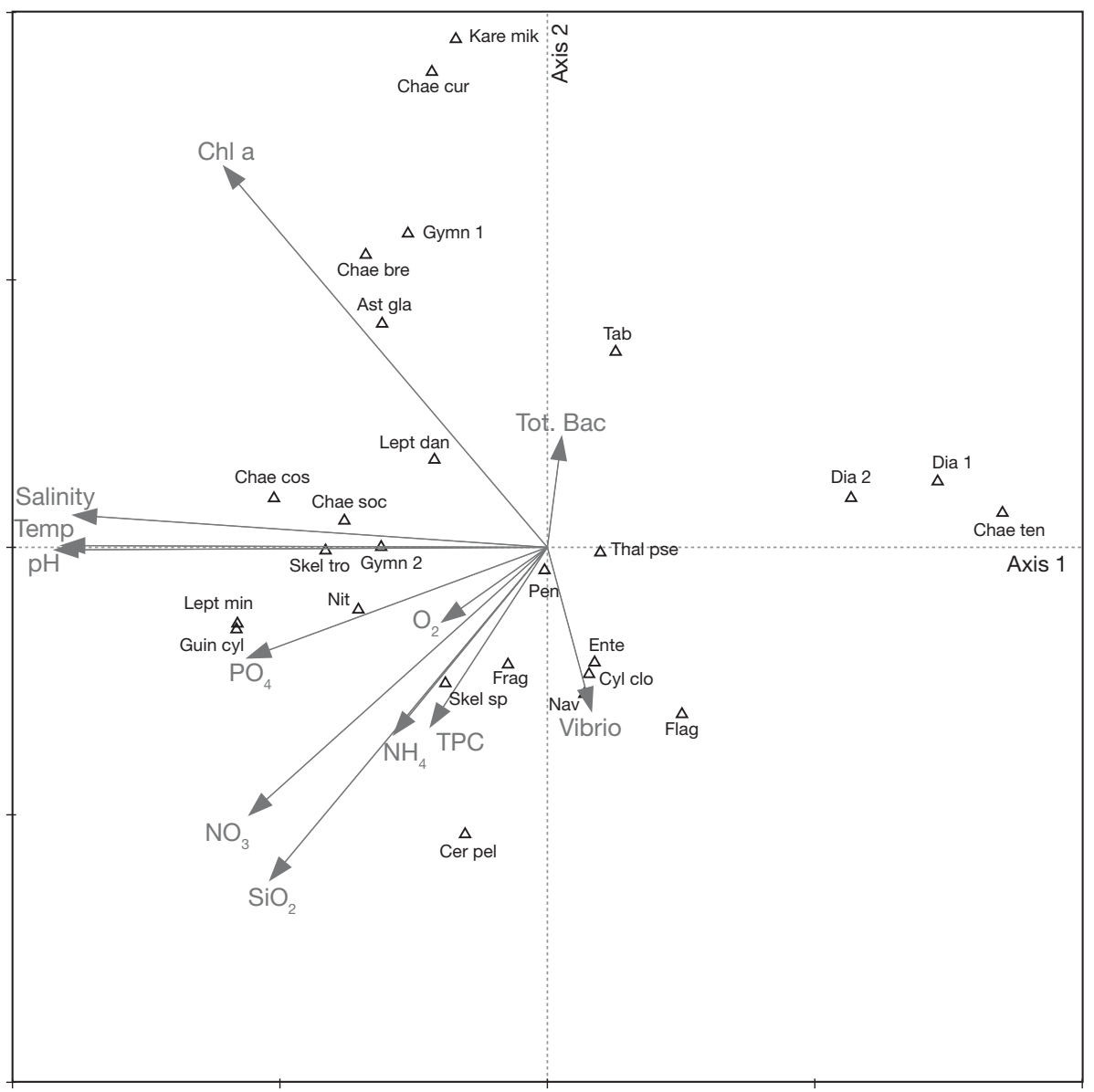

Fig. 5. Canonical correspondence analysis biplots for algal species abundance and environmental variables at the reference site. Abbreviations as in Fig. 4 and Cer pel = Cerataulina pelagica, Chae cos = Chaetoceros costatus, Cy clo = Cylindrotheca closterium, Dia 1 = Unidentified diatom sp. 1, Dia $2=$ Unidentified diatom sp. 2, Ente = Entomoneis spp., Frag = Fragilaria spp., Guin cyl = Guinardia cf. cylindrus, Gymn $1=$ Gymnodinium sp. 1, Gymn 2 = Gymnodinium sp. 2, Pen = Pennate diatom, Tab $=$ Tabellaria sp.

Flagellates were positively related to vibrios in all mesocosms as well as at the reference site (Figs. 4 \& 5); this suggests a high turnover rate of vibrios in the system. Production of vibrios reached approximately 0.35 to 0.45 cell doublings $\mathrm{d}^{-1}$ during the first $10 \mathrm{~d}$ of the experiment. The highest rates occurred in the sediment-inoculated mesocosms. A drop in density on Day 13 of the experiment (down to an average of 4000 cells $\mathrm{ml}^{-1}$ ) in all mesocosms could not be explained by high predation rates, but we speculate that this might have been due either to a temporary shortage of high quality organic substances or to a viral infection. A second increase in vibrio growth could be observed at the end of the mesocosm experiment. At this stage, the mesocosms had switched from a dominance of autotrophs to a dominance of heterotrophs. This could also be observed in the significant increase in flagellate numbers in the meocosms at the end of the experiment, i.e. on Day 17. Propagation of $V$. cholerae within a bacterioplankton assemblage has previously been demonstrated at rates of between 2.3 and 3.3 cell doublings $\mathrm{d}^{-1}$, but these rates were achieved in mesocosms lacking a natural living planktonic community (Mouriño-Pérez et al. 2003), in dilution cultures amended with glucose (Pinhassi \& Berman 2003), or in mesocosms without protozoan grazers (Wolden et al. 2006). Our mesocosms were inoculated with a natural microbial community with many trophic levels included (except larger zooplankton such as copepods), and thus correlated more closely to a natural system.

The results from the present study highlight the importance of further studies regarding vibrio growth and proliferation in the natural environment. We have shown that a diatom bloom can support vibrio growth. Furthermore, phytoplankton blooms, when recorded as high levels of chl $a$, should be used with caution as predictors for future vibrio epidemics, since the origin of the chl a probably has a significant effect on vibrio abundance. 
Acknowledgements. We thank 2 anonymous reviewers for their constructive comments. This work was supported by the Swedish International Development Cooperation Agency, Department for Research Cooperation grant 2006-10-30, and the Swedish Research Council grant 348-2005-3544.

\section{LITERATURE CITED}

Acinas SG, Rodriguez-Valera F, Petros-Alio C (1997) Spatial and temporal variation in marine bacterioplankton diversity as shown by RFLP fingerprinting of PCR amplified 16S rDNA. FEMS Microbiol Ecol 24:27-40

- Armada SP, Farto R, Perez MJ, Nieto TP (2003) Effect of temperature, salinity and nutrient content on the survival responses of Vibrio splendidus biotype I. Microbiology 149: 369-375

Braak CJF, Smilauer P (2002) CANOCO reference manual and CanoDraw for Windows user's guide: software for canonical community ordination (version 4.5). Microcomputer Power, Ithaca, NY

Brussaard CD, Kuipers PB, Veldhuis MJW (2005) A mesocosm study of Phaeocystis globosa population dynamics I. Regulatory role of viruses in bloom control. Harmful Algae 4:859-874

Chan KY, Woo ML, Lo KW, French GL (1986) Occurrence and distribution of halophilic vibrios in subtropical coastal waters of Hong Kong. Appl Environ Microbiol 52:1407-1411

Cook DW, DePaola A, McCarthy SA (2000) Direct plating procedure for the enumeration of total and pathogenic Vibrio parahaemolyticus in oyster meats. FDA, Office of Seafood, Gulf Coast Seafood Laboratory, Dauphin Island, AL

Deepanjali A, Kumar HS, Karunasagar I, Karunasagar I (2005) Seasonal variation in abundance of total and pathogenic Vibrio parahaemolyticus bacteria in oysters along the southwest coast of India. Appl Environ Microbiol 71: 3575-3580

> DePaola A, Nordstrom JL, Bowers JC, Wells JG, Cook DW (2003) Seasonal abundance of total and pathogenic Vibrio parahaemolyticus in Alabama oysters. Appl Environ Microbiol 69:1521-1526

Eiler A, Johansson M, Bertilsson S (2006) Environmental influences on Vibrio populations in northern temperate and boreal coastal waters (Baltic and Skagerrak Seas). Appl Environ Microbiol 72:6004-6011

Eilers H, Pernthaler J, Amann R (2000) Succession of pelagic marine bacteria during enrichment: a close look at cultivation-induced shifts. Appl Environ Microbiol 66:4634-4640

Eriksson L, Johansson E, Kettlauch-Wold N, Wold S (1999) Introduction to multi- and megavariante data analysis using projection methods (PCA \& PLS). Umetrics AB, Umeå, p 67-108

Fukami K, Simidu U, Taga N (1985) Microbial decomposition of phyto-and zooplankton in seawater. II. Changes in the bacterial community. PSZN I Mar Ecol 21:7-23

> Härnström K, Godhe A, Saravanan V, Karunasagar I, Karunasagar I, Rehnstam-Holm AS (2007) Tropic phytoplankton community development in mesocosms inoculated with different life stages. Mar Ecol Prog Ser 346:75-88

Holmquist L, Kjelleberg S (1993) Changes in viability, respiratory activity and morphology of the marine Vibrio sp. strain S14 during starvation of individual nutrients and subsequent recovery. FEMS Microbiol Ecol 12:215-224

> Huq A, Small EB, West PA, Huq MI, Rahman R, Colwell RR (1983) Ecological relationships between Vibrio cholerae and planktonic crustacean copepods. Appl Environ Microbiol 45:275-283
Islam MS, Miah MA, Hasan MK, Sack RB, Albert MJ (1994) Detection of non-culturable Vibrio cholerae O1 associated with a cyanobacterium from an aquatic environment in Bangladesh. Trans R Soc Trop Med Hyg 88:298-299

> Jonas RB, Tuttle JH (1990) Bacterioplankton and organic carbon dynamics in the lower mesohaline Chesapeake Bay. Appl Environ Microbiol 56:747-757

Kaneko T, Colwell RR (1973) Ecology of Vibrio parahaemolyticus in Chesapeake Bay. J Bacteriol 113:24-32

Karl DM (2007) Microbial oceanography: paradigms, processes and promise. Nat Rev Microbiol 5:759-769

Krishnakumar P, Bhat G (2007) Seasonal and interannual variations of oceanographic conditions off Mangalore coast (Karnataka, India) in the Malabar upwelling system during 1995-2004 and their influences on pelagic fishery. Fish Oceanogr 17:45-60

Kwan LC, Cheung DKF, Kam KM (2003) Peak occurrences of ciguatera fish poisoning precede cholera outbreaks in Hong Kong. Epidemiol Infect 131:621-626

> Lobitz B, Beck L, Huq A, Wood B, Fuchs G, Faruque ASG, Colwell RR (2000) Climate and infectious disease: use of remote sensing for detection of Vibrio cholerae by indirect measurement. Proc Natl Acad Sci USA 97:1438-1443

- Maeda T, Matsuo Y, Furushita M, Shiba T (2003) Seasonal dynamics in a coastal Vibrio community examined by a rapid clustering method based on $16 \mathrm{~S}$ rDNA. Fish Sci 69: 385-394

McCarthy SA, DePaola A, Cook DW, Kaysner CA, Hill WE (1999) Evaluation of alkaline phosphatase- and digoxigenin-labelled probes for detection of the thermolabile hemolysin (tlh) gene of Vibrio parahaemolyticus. Lett Appl Microbiol 28:66-70

Mouriño-Pérez RR, Worden AZ, Azam F (2003) Growth of Vibrio choleare O1 in red tide waters of California. Appl Environ Microbiol 69:6923-6931

> Mueller RS, McDougald D, Cusumano D, Sodhi N, Kjelleberg S, Azam F, Bartlett DH (2007) Vibrio cholerae strains possess multiple strategies for abiotic and biotic surface colonization. J Bacteriol 189:5348-5360

Munro PM, Colwell RR (1996) Fate of $V$. cholerae O1 in seawater microcosms. Water Res 30:47-50

Naviner M, Berge JP, Durand P, Le Bris H (1999) Antibacterial activity of the marine diatom Skeletonema costatum against aquacultural pathogens. Aquaculture 174:15-24

Nayak BB, Karunasagar I, Karunasagar I (2000) Bacteriological and physicochemical factors associated with Noctiluca milaris bloom along Mangalore South-west coast of India. Indian J Mar Sci 29:139-143

Oliver JD, Warner RA, Cleland DR (1982) Distribution and ecology of Vibrio vulnificus and other lactose-fermenting marine vibrios in coastal waters of the southeastern United States. Appl Environ Microbiol 44:1404-1414

Otta SK, Karunasagar I, Karunasagar I (1999) Bacterial flora associated with shrimp farms growing Penaeus monodon in India. J Aquacult Trop 14:309-318

Parsons T, Maita Y, Lalli C (1984) A manual of chemical and biological methods for seawater analysis. Pergamon, Oxford

Parvathi A, Kumar S, Bhanumathi A, Ishibashi M, Nischibuchi M, Karunasagar I, Karunasagar I (2006) Molecular characterization of thermostable direct haemolysin-related haemolysin (TRH)-positive Vibrio parahaemolyticus from oysters in Mangalore, India. Environ Microbiol 8:997-1004

> Pinhassi J, Berman T (2003) Differential growth response of colony-forming alpha- and gamma-proteobacteria in dilution culture and nutrient addition experiments from Lake Kinneret (Israel), the eastern Mediterranean Sea, and the Gulf of Eilat. Appl Environ Microbiol 69:199-211 
Porter KG, Feig YS (1980) The use of DAPI for identifying and counting aquatic microflora. Limnol Oceanogr 25:943-948

Raghunath P, Karunasagar I, Karunasagar I (2007) Evaluation of an alkaline phosphatase-labeled oligonucleotide probe for detection and enumeration of Vibrio spp. from shrimp hatchery environment. Mol Cell Probes 21:312-315

Rehnstam AS, Bäckman S, Smith DC, Azam F, Hagström Å (1993) Blooms of sequence-specific culturable bacteria in the sea. FEMS Microbiol Ecol 102:161-166

Salvesen IK, Reitan I, Skjermo J, Øie G (2000) Microbial environment in marine larviculture: impacts of algal growth rates on the bacterial load in six microalgae. Aquacult Int 8:275-287

Siebuth JM (1968) The influence of algal antibiosis on the ecology of marine microorganisms. In: Droop MR (ed) Advances in microbiology, Vol 1. Academic Press, New York, p 63-94

Simidu U, Tsukamoto K (1980) A method of the selective isolation and enumeration of marine Vibrionaceae. Microb Ecol 6:181-184

Smith DC, Steward GF, Long RA, Azam F (1995) Bacterial mediation of carbon fluxes during a diatom bloom in a mesocosm. Deep-Sea Res 42:75-97

Subrahmanyan R (1958) Ecological studies on the marine phytoplankton on the west coast of India. Mem Indian Bot Soc 1:145-151

Subrahmanyan R, Sarma AHV (1960) Studies on the phytoplankton of the west coast of India. III. Seasonal variation of the phytoplankton and the environmental factors. Indian J Fish 7:307-336

Editorial responsibility: Curtis Suttle, Vancouver, British Columbia, Canada
Thompson FL, Austin B, Swings J (2006) The biology of Vibrios. ASM Press, Washington, DC

Thomsen HA (1992) Plankton i de inre danske farvande, Vol 11. Dansk Miljøstyrelse, Copenhagen

Throndsen J, Hasle G, Tangen K (2003) Norsk kystplanktonflora. Almater Forlag, Oslo

Tomas C (1997) Identifying marine phytoplankton. Academic Press, San Diego, CA

Urakawa H, Yoshida T, Nishimura M, Ohwada K (2000) Characterization of depth-related population variation in microbial communities of a coastal marine sediment using 16S rDNA-based approaches and quinone profiling. Environ Microbiol 2:542-554

Utermöhl H (1958) Zur Vervollkommnung der quantitativen Phytoplankton Methodik. Mitt Int Ver Limnol 9:1-38

Viso AC, Pesando D, Baby C (1987) Antibacterial and antifungal properties of some marine diatoms in culture. Bot Mar 30:41-45

Wold S, Ruhe A, Wold H, Dunn WJ (1984) The collinearity problem in linear regression. The partial squares (PLS) approach to generalized inverses. SIAM J Sci Stat Comput 5:735-743

Worden AZ, Seidel M, Smriga S, Wick A, Malfatti F, Barlett D, Azam F (2006) Trophic regulation of Vibrio cholerae in coastal marine waters. Environ Microbiol 8:21-29

Yu C, Bassler BL, Roseman S (1993) Chemotaxis of the marine bacterium Vibrio furnissii to sugars - a potential mechanism for initiating the chitin catabolic cascade. J Biol Chem 268:9405-9409

ZoBell CE (1941) Studies on marine bacteria. I. The cultural requirements of heterotrophic aerobes. J Mar Res 4:42-75

Submitted: December 31, 2008; Accepted: July 30, 2009

Proofs received from author(s): November 14, 2009 